DOI: https://doi.org/10.32839/2304-5809/2019-1-65-10

УДК $355.23 ; 339.19$

Балендр А.В.

Національна академія Державної прикордонної служби України імені Богдана Хмельницького

\title{
ЕТАПИ РОЗРОБКИ ГАЛУЗЕВОЇ РАМКИ КВАЛІФІКАЦІЙ ДЛЯ ПІДГОТОВКИ ПРИКОРДОННИКІВ КРАЇН ЄВРОПЕЙСЬКОГО СОЮЗУ
}

\begin{abstract}
Анотація. У статті розкрито етапи розробки галузевої рамки кваліфікацій для підготовки прикордонників країн Європейського Союзу (СС). Проаналізовано сучасний досвід европейських прикордонних відомств 3 щодо розробки галузевої рамки кваліфікацій для підготовки прикордонників країн ЄС. Представлено три етапи розробки ГРК: перший - безпосередньо розробка ГРК, другий - перевірка валідності, та третій етап - інтеграція на національному рівні. Детально було розглянуто перший етап, який включав розробку профілів компетентностей та результатів навчання, створення функціональної карти прикордонної сфери, надання консультацій та перевірку професійних компетентностей. Формулювання результатів навчання передбачало укладання таблиць для перехресної перевірки результатів навчання та професійних компетентностей, відомчу перевірку відповідності отриманих результатів. Підкреслено важливість вивчення досвіду розробки ГРК для підготовки прикордонників країн ЄС для сучасного етапу розвитку системи професійної освіти і підготовки українського прикордонного відомства.
\end{abstract}

Ключові слова: прикордонники, підготовка персоналу, країни Європейського Союзу, галузева рамка кваліфікацій.

Balendr Andrii

National Academy of the State Border Guard Service of Ukraine named after Bohdan Khmelnytsky

\section{STAGES OF DEVELOPMENT OF THE SECTORAL QUALIFICATIONS FRAMEWORK FOR PREPARATION OF BORDER GUARDS OF THE EUROPEAN UNION COUNTRIES}

Summary. The article describes the stages of development of the Sectoral Qualifications Framework for the preparation of border guards of the European Union (EU) countries. The current experience of the European border guard agencies regarding the development of the Sectoral Qualifications Framework (SQF) for the preparation of border guards of the EU countries in the framework of the Frontex Agency international project has been analyzed. The three stages of the development of the SQF have been presented: the first is the development of the SQF, the second is validation, and the third stage - integration at the national level. The first stage was considered in detail, which included developing competency profiles and learning outcomes, creating a functional map of the border guard sphere, providing counseling and testing of professional competencies. The formulation of learning outcomes included the compilation of tables for cross-checking learning outcomes and professional competencies, and departmental testing of compliance with the results. Special attention has been payed to studying the experience of developing the SQF for the preparation of border guards of the EU countries for the modernization of the system of professional training of the Ukrainian border guard agency.

Keywords: border guards, training of personnel, countries of the European Union, sectoral qualifications framework.

Постановка проблеми. Сьогодні, у зв'язку 1 із зростанням обсягу професійних функцій прикордонників, ускладненням оперативно-службових завдань 3 охорони державного кордону України, а також створенням системи інтегрованого управління кордоном, великого значення набувае оптимізація підготовки персоналу Державної прикордонної служби України (ДПСУ). Тому, сьогодні не викликае сумнівів питання актуальності вивчення передового досвіду інших країн, а особливо - країн Європейського Союзу, в прикордонних відомствах яких останнім часом відбуваються значні зміни. Система професійної підготовки прикордонників країн ЄС сьогодні проходить процес узгодження із принципами Болонського та Копенгагенського процесів, що, поміж іншого, передбачае впровадження Галузевої рамки кваліфікацій для підготовки прикордонників країн СС (ГРК). Таким чином, з метою виконання завдань керівництва ДПСУ щодо підвищення ефективності підготовки персоналу у відомчих навчальних закладах, необхідно вивчити досвід запровадження даних інновацій для подальшої апроксимації системи професійної підготовки ДПСУ до стандартів провідних европейських країн.

Мета статті - висвітлити етапи розробки ГРК для підготовки прикордонників Агенщії FRONTEX $з$ метою подальшого впровадження набутого досвіду в систему профресійної підготовки персоналу ДПСУ.

Аналіз останніх досліджень і публікацій. Як показав аналіз літературних джерел, проблема вдосконалення професійної підготовки прикордонників була предметом уваги багатьох представників військової та педагогічної науки, таких як: І. Грязнов, О. Мацишин, О. Діденко, О. Богданюк, Л. Боровик. Компетентністний підхід в освіті досліджували: О. Андрощук, Ю. Рашкевич. Дослідженнями професійної підготовки фахівців з охорони кордонів зарубіжних країн займались Н. Ринденко, І. Блощинський [1]. Питання розробки та впровадження національних та галузевих рамок кваліфікацій вивчали й закордонні дослідники: В. Заславський, М. Нікітченко, Л. Філіпова. Проте, наші розвідки засвідчили, що на- 
разі досліджень етапів розробки ГРК для підготовки прикордонників, практично не існуе.

Виділення невирішених раніше частин загальної проблеми. В умовах посилення процесів глобалізації у всіх сфрерах економічного та соціального життя розробка механізмів підтримки навчання протягом життя і трудової мобільності набувають особливого значення, як для індивідуумів, так і для компаній і навіть держав. Засновані на узгоджених між собою національних рамках кваліфрікацій, ГРК дозволяють, $з$ одного боку, зіставити результати навчання різних освітніх та сертифрікаційних систем, а 3 іншого боку, зберегти індивідуальні особливості нащіональних систем освіти та інституційних засад ринку праці. Розробка ГРК є ресурсоємним і тривалим процесом, що вимагають узгоджених дій усіх зацікавлених сторін [2].

Рамки кваліфікацій в предметних областях повинні бути інструментом для обміну інформацією між навчальними закладами різних країн, 3 допомогою якого можна буде зіставити результати навчання, виявити кращі практики і підвищити якість освіти. Крім того, рамки кваліфрікацій також повинні виконувати фрункції зв'язку між системою освіти і вимогами ринку праці [3].

Виклад основного матеріалу. Потреба відповідати сучасним вимогам щодо розвитку системи освіти та підготовки прикордонників спонукала Агенцією FRONTEX у жовтні 2011 року ініціювати проект з розробки ГРК для підготовки прикордонників країн ЄС, для чого було сорормовано робочу групу з 40 експертів. Група включала фрахівців суто прикордонної сфери діяльності, а також 3 питань підготовки 320 прикордонних відомств, 19 країн-членів $\mathrm{CC} \mathrm{і} \mathrm{асоційованих} \mathrm{кра-}$ їн Шенгенської зони: Австрія, Бельгія, Кіпр, Чеська Республіка, Естонія, Фінляндія, Франщія, Німеччина, Угорщина, Ірландія, Італія, Латвія, Мальта, Нідерланди, Польща, Румунія, Словаччина, Іспанія, Великобританія та партнерської організації DCAF (Женевський центр демократичного контролю над збройними силами). 3 метою забезпечення узгодженості з іншими освітніми інструментами Агенції FRONTEX, такими як Уніфріковані програми підготовки (УПП), розробка ГРК для прикордонної сфери діяльності розпочалась з роботи групи експертів, яких було раніше залучено до розробки УПП для базової підготовки прикордонників, УПП для підготовки офріцерів середнього рівня, курсу FRONTEX для підготовки середнього рівня та навчальних програм вищої освіти. Також до співпраці було залучено експертів, із досвідом роботи з Агенцією FRONTEX. Зусилля усіх експертів було об'єднано для досягнення амбітної мети - розробки європейської рамки кваліфікацій для прикордонного профресійного сектору (галузі) [4].

Задум створення ГРК спершу було обговорено в рамках національної мережі координаторів тренінгів FRONTEX, після цього обговорення поширилось на значно ширший форум фрахівців з підготовки персоналу для прикордонних відомств, метою якого було визначення траєкторій розвитку спільних европейських стандартів для середньої та вищої прикордонної освіти. В листопаді 2011 року відбулась офіційна зустріч з цього питання на Мальті, у Мальтійському університеті, який є партнерською Академією FRONTEX в рамках першої конференції «Свропейські навчальні програми з охорони кордонів». Інтерес до галузевих рамок був суттевим, оскільки представники країн ЄC розуміли потенціал і стратегічні наслідки створення европейської кваліфікаційної рамки для підготовки персоналу прикордонних відомств Європи. Відповідно, в січні 2012 року було надіслано запрошення для призначення експертів з відповідним досвідом (експертиза в професійній copepi, підготовка та освіта на всіх рівнях) всім країнам-членам та асоційованим-членам Шенгенгенського договору, пізніше була створена проектна група 3 представників країн ЄС [5].

Варто зазначити, що безпосередньому процесу розробки передував окремий етап, а саме - визначення профрілів професійних компетентностей для 6 та 7 кваліфікаційних рівнів (Бакалаврат та Магістратура). У липні 2011 року було створено невелику групу експертів в рамках проекту розробки програм вищої освіти. На той час проект був спрямований лише на розробку профілів компетентностей для 6 та 7 рівнів, які мали скласти основу для подальших спільних програм прикордонної освіти середнього та високого рівнів.

Проте, пізніше стало очевидним, що набагато вигідніше фрактично розробити галузеву (секторальну) рамку, основану на результатах навчання, і яка відповідала б $Є Р К$, і охоплювала б не тільки 6 та 7 рівні компетенціі, а комплексно відображала б усю освіту й підготовку прикордонної сорери діяльності. Було визначено, що розробка ГРК для підготовки прикордонників включатиме як профресійні, так і академічні кваліфікації, оскільки значна частина системи підготовки прикордонників є профресійною. Отже, акцент проекту змістився зі стандартів вищої освіти на інтегрований підхід до підготовки прикордонників взагалі та включення кваліфрікації усіх рівнів. Метою було забезпечити послідовність та узгодженість між рівнями, прогрес навчання та цілісність продукту, що розроблявся.

Таким чином процес розробки та апробації ГРК включав 3 етапи: етап розробки, етап перевірки валідності та етап інтеграції на національному рівні.

Етап 1. Розробка ГРК.

Цей етап включає розробку профрілів компетентностей та розробку результатів навчання. Робота 3 розробки профрілів компетентностей передбачає створення фрункціональної карти прикордонної сорери (робота у складі визначених робочих груп); надання консультацій та перевірку профресійних компетентностей (проведення консультацій національними представниками). Проведення заходів щодо формулювання результатів навчання передбачає роботу в складі визначених робочих груп; укладання таблиць для перехресної перевірки результатів навчання та професійних компетентностей, їх перевірку (відомчу перевірку відповідності отриманих результатів).

Етап 2. Перевірка валідності ГРК.

Після розробки ГРК відбувається процес перевірки їі валідності, тобто встановлення ступеню ïi коректності та готовності. Цей етап включає виконання низки послідовних заходів:

1. Перевірка представниками европейських країн; запровадження та узгодження механізму 
контрою якості ГРК; розробка «Довідника з інтеграції фундаментальних прав у підготовку прикордонників".

2. Зовнішне незалежне оцінювання.

3. Схвалення керівництвом Агенції FRONTEX.

4. Офіційний запуск та подальше впровадження ГРК.

Етап 3. Інтеграція на національному рівні.

Цей етап передбачае такі заходи: створення Експертного комітету ГРК; проведення семінарів для перекладачів; підготовка мультиплікаторів; огляд курсів підготовки Агенції FRONTEX та їх узгодження з ГРК [3].

В рамках цієї статті ми розглянемо лише перший етап, а саме - розробку ГРК. Необхідно зазначити, що він включав проведення широкомасштабної роботи 3 відображення професійних функцій і завдань прикордонної сфрери діяльності на всіх рівнях. Це потребувало повного опису знань, навичок та компетентностей, необхідних для виконання завдань 3 охорони кордону. Робота розпочалася на підставі того, що основною метою навчання у цьому професійному секторі $€$ отримання знань, навичок та вмінь або «продресійних компетентностей» для ефрективної організації охорони кордону. Тому результати навчання в ГРК повинні стосуватися всіх компетентностей з охорони кордону. Перш за все, це передбачало створення списку профресійних компетентностей, які повинні відображати і охоплювати всі завдання прикордонників, представляти повну картину роботи прикордонного відомства, на основі якої в подальшому будуть визначені вимоги до підготовки персоналу. Профресійні компетентності були сфрормульовані на основі заголовків, які робоча група узгодила шляхом визначення обсягу профресійних фрункцій персоналу прикордонних відомств. Компетентності було написано більш "професійною мовою» і за форматом вони були близькі до професійних стандартів.

Цей комплексний набір професійних компетентностей був використаний для побудови рамки компетентностей або документа «Профрілі профресійних компетентностей», що є частиною пакету ГРК. Він був розроблений для забезпечення профресійної відповідності стандартів навчання та безпосереднього зв'язку підготовки 3 професійними функціями та вимогами. Профрілі профресійних компетентностей ГРК були основою для визначення стандартів підготовки (вимог до освітнього процесу і підготовки).

Отже, наступний етап - проведення консультації та перегляд профрілів профресійних компетентностей. У ході серії семінарів, присвячених розробці продесійних компетентностей, експерти країн ЄС зазначили, що їх відповідні прикордонні відомства також почали переглядати свої національні профресійні стандарти, і що профрілі профресійних компетентностей ГРК, хоча і на стадії робочого документа, були корисним інструментом для надання допомоги у їх перевірці й модернізації.

Ці обговорення обумовили необхідність послідовний перегляду профрілів професійних компетентностей, їх порівняння з професійними стандартами національних прикордонних відомств. Члени робочих групи отримали завдання взяти 3 собою отримані результати групової роботи та провести їх перевірки у порівнянні з національним професійними стандартами відповідних прикордонних відомств. Конкретні вказівки були надані членам робочих груп 3 точки зору методології та процесу перегляду, а також були надані конкретні рекомендації щодо включення до процесу перевірки експертів профресійної сфрери, щоб переконатись, що фрахівці, які безпосередньо виконують ці профресійні функції мали можливість переглянути профілі компетентностей визначені робочою групою.

Головним завданням національних експертів було надати оцінку переліку компетентностей у профрілях, розроблених для рівнів 4, 5 (базовий рівень), 6 (середній рівень) та 7 (високий рівень), а також для виявлення упущень або відсутніх компетентностей. Сформульовані питання були спрямовані на визначення того, чи адекватно відображені в профрілях профресійних компетентностей фрункції прикордонного відомства. Експертам було поставлено завдання спланувати свої національні тренінги, а також визначити аспекти підготовки, які не були враховані в рамці продесійних компетентностей.

Результати процесу перегляду професійних компетентностей були представлені робочій групі, завданням якої було провести аналіз, обговорення та узгодити зміни, стосовно робочого документа. Експертами були надані окремі рекомендащії щодо запровадження окремих елементів у профілі компетентностей. Групові обговорення були проведені із врахуванням основних принципів ГРК:

інклюзивність;

репрезентативність;

інтеграція різноманітності та підтримка специфіки ГРК (має стосуватись виключно прикордонної сорери) [4].

Після цього робоча група приступила до розробки результатів навчання. Ще на заключному етапі розробки профрілів профресійних компетентностей робоча група ініціювала розробку першого проекту результатів навчання і провела їх перехресну перевірку з профілями компетентностей. Ірунтуючись на новому переробленому варіанті профілів профресійних компетентностей, після консультацій національних експертів, робоча група переглянула та ухвалила кінцевий варіант списку результатів навчання. Вони були ретельно визначені та наведені у відповідності до дескрипторів навчання за ЄРК для кожного рівня. Для визначення результатів навчання було використано таксономію активних дієслів Б. Блума [6], але у подальшому увага була приділена іншим елементам, таким як: контекст підготовки (сорера застосування або обсяг навчання); вид навчання (отримання знань, умінь або компетентностей); тематика (конкретна або загальна); можливість оцінювання (чи можна це оцінити).

Основними проблемами, що виникали при розробці результатів навчання було практичне застосування принципу «ієрархії результатів на-

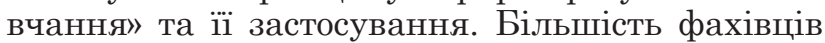
у робочих групах мали досвід розробки навчальних програм навчальних програм, але дуже мало людей мали досвід визначення результатів навчання на рівні програми або, зокрема, результатів навчання на галузевому рівні. 
Тенденція до написання результатів навчання нижчого рівня (конкретно, деталізовано, на рівні навчального плану) була спочатку значною. Так само більшість експертів виявили, що легше писати результати навчання у вигляді знань, на відміну від навичок або компетентностей. Особливо складним було формулювання результатів навчання компетентностей, оскільки визначення компетентності за СРК та поняття «відповідальності» та «автономії» не були знайомі багатьом експертам. Пройшов деякий час, перш ніж усі члени робочих груп зрозуміли характеристики результатів навчання: конкретні, об'єктивні, досяжні, корисні, актуальні, які можна оцінити та які знаходяться на відповідному рівні. Наразі в рамках проекту TUNING опрацьовано практичні поради щодо фрормулювання результатів навчання [7].

В процесі розробки результатів навчання мала місце тенденція постійно повертатись до профрілів професійних компетентностей і перевіряти чи всі професійні компетентності будуть охоплені процесом навчання, i чи узгоджені результати навчання 3 профресійними компетентностями [8]. На основі цього досвіду було розроблено Таблиці для перехресної перевірки для кожного рівня ГРК, для проведення перевірки й узгодження результатів навчання і профресійних компетентностей.

Цей етап слугував інструментом внутрішньої валідацї, використання якого спричинило значну модифікацію розроблених результатів навчання. Перехресна перевірка виявила, що деякі результати навчання були недостатньо конкретними, деякі охоплювали занадто багато матеріалу, а також матеріалу різного типу (наприклад, два результати навчання в одному реченні). Таким чином, деякі профрілі профресійних компетентностей були повторно перевірені і доопрацьовані.

Таблиці для перехресної перевірки результатів навчання $є$ важливим елементом розробки навчальних курсів. Під час проведення Агенцією FRONTEX навчального курсу 3 розробки програм навчання, відповідно ГРК та Болонського і Копенгагенського процесів, на якому ав- тор навчався у червні 2017 року в партнерській академії FRONTEX в м. Іннсбрук, Австрія, стало очевидним наскільки корисним виявився даний інструмент. Завдяки цим таблицям стало чітко видно, які результати навчання сприяють досягненню визначеної продесійної компетентності.

Розглянуті етапи розробки ГРК дозволяють зробити висновок про їх обгрунтованість, логічність і послідовність впровадження, що обумовлюе вивчення та узагальнення даного досвіду з метою його використання для модернізації системи підготовки персоналу ДПСУ.

Висновки i пропозиції. Сучасний досвід розробки ГРК для підготовки прикордонників країн $\mathrm{CC} є$ важливим для сучасного етапу розвитку системи профресійної освіти і підготовки ДПСУ. Висвітлені етапи створення такого визначного у європейському масштабі освітнього інструменту повинні сприяти усвідомленню важливості розробки й впровадження ГРК правоохоронними відомствами усіх країн, що в уможливить відповідність високим стандартам провідних країн ЄС, посилить мобільність українських прикордонників у загальноевропейській системі прикордонної підготовки та створить умови для акредитації національних навчальних курсів на европейському рівні.

В статті представлено три етапи розробки ГРК: перший етап - безпосередньо розробка ГРК, другий - перевірка валідності ГРК, та третій етап - інтеграція на національному рівні. Детально було розглянуто перший етап - розробку ГРК, який включав розробку профілів компетентностей та результатів навчання, створення функціональної карти прикордонної сфери, надання консультацій та перевірку профресійних компетентностей. Формулювання результатів навчання передбачало укладання таблиць для перехресної перевірки результатів навчання та профресійних компетентностей, відомчу перевірку відповідності отриманих результатів.

Перспективами подальших наукових розвідок вважаємо дослідження та узагальнення досвіду апробації ГРК Агенції FRONTEX 3 метою його використання для підвищення ефрективності підготовки українських прикордонників.

\section{Список літератури:}

1. Bloshchynskyi I. Enhancement of cadets' practical training at the National Academy of the State Border Guard Service of Ukraine named after Bohdan Khmelnytskyi. Science and Education. 2017. Vol. 4. Pp. 5-10.

2. Розробка та впровадження галузевої рамки кваліфікацій в галузі знань «Інформаційні технології» / В.А. Заславський, М.С. Нікітченко, Л.Л. Омельчук, О.М. Ямкова. - Київ: Київський національний університет, 2016. «Добродій»- 88 с

3. Вольпян Н.С., Тихомиров В.В., Разгулин А.В., Парчевская Л.Н., Сергеев С.Ф., Харитонова И.Ю., Чернышенко С.В. Проектирование секторальных рамок квалификаций в области информатики. - М.: Издательство МаксПресс, 2015. - 220 с.

4. Sectoral Qualifications Framework for Border Guarding (volume 1), FRONTEX, Warsaw, Rondo ONZ 1, 2013. - 173 p.

5. Інформаційно-освітня веб-платформа Virtual Aula. [Електронний ресурс]. - Режим доступу: http://aula.frontex.europa.eu/?l=en.

6. Bloom B.S. (Ed.) (1956). Taxonomy of educational objectives. The Classification of Educational Goals. Handbook I: Cognitive Domain. New York, Toronto: Longmans, Green.

7. Захарченко В.М., Луговий В.І., Рашкевич Ю.М., Таланова Ж.В. Розроблення освітніх програм. Методичні рекомендації / В.М. Захарченко, В.І. Луговий, Ю.М. Рашкевич, Ж.В. Таланова / За ред. В.Г. Кременя. К.: ДП «НВЦ «Пріоритети», 2014. - 120 с.

8. Балендр А. Характеристика рівнів галузевої рамки кваліфікацій для підготовки прикордонників країн Європейського Союзу в академічній освіті. Педагогічний дискурс. 2017 (22), 9-14. [Електронний ресурс]. Режим доступу: http://ojs.kgpa.km.ua/index.php/peddiscourse/article/view/9. 